6. Rodbell, M. J. biol. Chem. 241, 130-139 (1966)

7. Codina, J., Hildebrandt, J.D., Birnbaumer, L. \& Sekura, R.D. $J$ hiol Chem 259 11408-11418 (1984)

8. Hildebrandt, J.D. et al. J. biol. Chem. 260, 14867-14872 (1985)

LOGOThETIS ET AL. REPLY - Although Birnbaumer and Brown make no such claim in their paper ${ }^{1}$, they now maintain that $\alpha_{4||}$ is the subunit of $G_{k}$ which activates the $\mathrm{K}^{+}$channel. They reported no experiments with resolved $G_{k}$ subunits, only with $\alpha \beta \gamma$-heterotrimers. In contrast, we studied purified $\alpha$ or $\beta \gamma$ and found that the $\beta \gamma$ activates the $\mathrm{K}^{+}$ channel. We were surprised that $\beta \gamma$ mediated the $\mathrm{K}^{+}$channel activation because we also began with the assumption that $\alpha$ would be the only effector. Birnbaumer and Brown view our findings and theirs as necessarily mutually exclusive. We disagree and suggest that the truth may be more complicated and more interesting. Our negative results cannot rule out some role for $\alpha$ subunits, but our positive findings with $\beta \gamma$ at $\mathrm{pM}$ concentrations strongly support a role for $\beta \gamma$ in activating the $\mathrm{K}^{+}$channel in the heart. The challenge for the future will be to define precise functions for the subunits.

Contrary to the assertion of Birnbaumer and Brown, our results with $\beta \gamma$ are not due to contaminating $\alpha$ protein. The figure shows that $200 \mathrm{pM} \beta \gamma$, a concentration 100-fold lower than we used previously, results in activation equivalent to $200 \mathrm{pM} \mathrm{G}_{\mathrm{k}}$ (Fig. 1, ref. 1). We calculate there is less than 0.5 per cent contamination of $\alpha$ in the $\beta \gamma$ preparation, both from densitometry of a highly overloaded SDS-polyacrylamide gel and by pertussis toxin catalysed $\left[{ }^{32} \mathrm{P}\right] \mathrm{ADP}$-ribosylation. If a contaminating $\alpha$ is responsible, it must be strongly activating the $\mathrm{K}^{+}$channel at less than $1 \mathrm{pM}$, a concentration below that at which Yatani et al. see effects of $\mathrm{G}_{\mathrm{k}}$ on the $\mathrm{K}^{+}$channel. It is important to stress that any residual $\alpha$ subunit in our $\beta \gamma$ preparations would be unactivated. Our $\beta \gamma$ preparations have never been in GTP $\gamma \mathrm{S}$. Fluoride activation of the $\alpha_{39}$ protein is readily reversible by removal of fluoride ${ }^{3}$. Fluoride was removed from the $\beta \gamma$ preparations by one (or two) steps of gel filtration or chromatography before use. Although our results are now shown to occur in the same concentration range as those cited by Yatani et al., there may well be differences due to different patch channel density, detergent, methods of protein determination or sources of atrial membranes and $\mathrm{G}$ proteins.

Birnbaumer and Brown suggest that our inability to see activation of the $\mathrm{K}^{+}$ channel by pure $\alpha$ subunits is because they are denatured or unactivated. We tested the function of the particular preparations of $\alpha_{39}$ and $\alpha_{41}$ used. The $\alpha_{39}$ subunit was activated at $5 \mathrm{mM} \mathrm{Mg}{ }^{2+}$, not at $2 \mathrm{mM} \mathrm{Mg}^{2+}$. It has a brisk GTPase activity at $22^{\circ} \mathrm{C}$ which is inhibited by $200 \mathrm{nM}$ GTP $\gamma$ S. Thus, nucleotides are turning over at the active site. Although the $\alpha$ subunits were in excess of GTP $\gamma$ S during activation, we calculate from the $K_{\mathrm{D}}(30$ $\mathrm{nM})$ that we determined ${ }^{4}$ for $\alpha_{39}$ and $\alpha_{41}$ that the solution applied to the patch contained approximately $9 \mathrm{nM}$ GTP $\gamma \mathrm{S}$ liganded $\alpha$ subunit, a concentration about 40 times greater than necessary to activate $\mathrm{K}^{+}$channels according to Yatani et al. The minor $(40 \mathrm{~K})$ pertussis toxin substrate from brain, described by $u s^{5}$ has not yet been purified but is always present in small amounts in the $\alpha_{39}$ preparation.

A strong control for the specificity of the action of $\beta \gamma$ is inhibition of its effect by $\alpha$ subunits, presumably by the formation of inactive heterotrimers. Birnbaumer and Brown speculate that a contaminating protease in the $\alpha$ preparation is responsible. But when we incubate our $\alpha$ with $\beta \gamma$ for $40 \mathrm{~min}$ at $30^{\circ} \mathrm{C}$ we find no breakdown of either subunit on subsequent SDS-PAGE. Birnbaumer and Brown's suggestion that a protease in the $\alpha$ preparation inactivates a phospholipase in the $\beta \gamma$ preparation is sheer speculation. Finally, the observation that $\alpha$ decreases $\mathrm{Ca}$ channel conductance in NG108 cells ${ }^{6}$ has nothing to do with $\mathrm{K}^{+}$ channels in heart cells.

Thus we have activated the $\mathrm{K}^{+}$channel with picomolar concentrations of $\beta \gamma$ subunits alone. GTP $\gamma \mathrm{S}$-liganded $\alpha$ subunits at $\mathrm{nM}$ concentrations did not activate the channel. Birnbaumer and Brown should test resolved subunits to determine individual activities of their $\alpha_{40}$ and $\beta \gamma$.

Diomedes E. LOGothetis YOSHIHISA KURACHI JONAS GALPER

Eva J. Neer

Cardiovascular Division

Brigham \& Women's Hospital,

Boston, Massachusetts 02115, USA

Yatani, A., Codina, J., Brown.

. Logothetis, D.E.. Kurachi, Y., Galper, J., Neer, E.J. \& Clapham, D.E. Nature 325, 321-326(1987)

. Higashjima, T. et al. J. biol. Chem. 262,752-756 (1987).

4. Huff, R.M. \& Neer, E.J. J. biol. Chem. 261, 1105-1110 (1986).

Neer, E.J., Lok, J.M. \& Wolf, L.G. J. biol. Chem. 259 14222-14229 (1984)

6. Hescheler, J., Rosenthal, W., Trautwein. W. \& Schultz, G Nature 325, 445-447 (1987)

\section{Climate and reproduction of yellowstone grizzlies}

SiR-For more than 50 years before 1968 , grizzly bears were permitted free access to several large open-pit garbage dumps inside Yellowstone National Park. Throughout the summer, grizzlies congregated at these sites in large numbers (up to 170 individuals) to feed undisturbed on refuse. Between 1968 and 1971 these dumps were closed abruptly and since then most Yellowstone grizzlies have had to find sufficient natural summer forage to compensate for the loss of garbage. This situation may suit many conserva- tionists and land managers; but it has almost certainly imposed additional hardship on a population beset with low reproductive rate, high human-induced mortality ${ }^{1}$ and severe habitat encroachment.

Picton analysed climate and reproduction of grizzly bears in Yellowstone National Park ${ }^{2}$ and concluded that climatic effects, specifically temperature and precipitation from October to May, were responsible for the decline in grizzly bear litter sizes observed since 1972 . We contend that the abrupt closure of the openpit garbage dumps was a more likely cause of this decline.

To evaluate the relative effects of climate and dump closures on grizzly reproduction properly, climatic factors should be controlled for by analysis of covariance. Using such an analysis, Knight and Eberhardt ${ }^{1}$ recently showed that after adjusting for differences in climate, mean annual litter sizes were significantly larger from 1959 to 1970 than from 1971 to 1981 . This suggests that the dump closures, rather than climate, probably caused the decline. Our own analysis of covariance shows that when individual litter sizes are adjusted to a common climate index, the mean for the years before the dump closures $\left(1959-69, x_{\text {adi }}=\right.$ 2.17 cubs per litter) was significantly larger than the mean for the years 1973$1981\left(x_{\text {adj }}=1.95, P=0.02\right.$; manuscript in preparation). We omitted litters born between 1970 and 1972 because they were conceived during the period of major dump closures $(1969-71)^{3}$.

Picton $^{2}$ further considered the combined effects of climate and carrion on mean grizzly litter sizes. Because these two predictor variables are undoubtedly intercorrelated, we question the validity of combining the two as he did. It would be more appropriate to control for the effects of each variable statistically, using either path analysis or a partial correlation analysis. We have been unable to do this, however, because neither the carrion data nor the method of deriving an index of relative availability is accessible. The indices themselves are in press ${ }^{4}$, but they include only the values of +1 and -1 , suggesting little variation among years in carrion availability. Presumably there are valid data underlying these indices, but Picton has yet to make them available or describe precisely how the indices were derived.

John J. CRAIGHEAD

Wildlife-Wildlands Institute, 5200 Upper Miller Creek Road, Missoula, Montana 59803, USA

1. Knight, R.R. \& Eberhardt, L.L. Ecology 66, 323-334 (1985)

. Picton, H.D. Nature 274, $888-889$ (1978).

U.S. Dept. Interior, Natl. Park Serv., Proposed Grizzly Bear Management Program, Yellowstone National Park (1974).

4. Picton. H.D. \& Knight, R.R. Proc. 6th Int. Conf. Bear Res. $\& M g m t$. (in the press) 